\title{
Purification and Characterization of a Pregastric Esterase From a Hygienized Kid Rennet Paste
}

\section{V. Calvo and J. Fontecha}

Dpto. de Ciencia y Tecnología de Productos Lácteos, Instituto del Frío (CSIC), C/ José Antonio Novais, 10

Ciudad Universitaria, 28040 Madrid, Spain.

\section{ABSTRACT}

Rennet pastes obtained by maceration of gastric tissues from suckling kids are used traditionally to produce some artisanal cheeses in Spain. Besides milkclotting function, rennet pastes provide proteolytic activity and lipolytic system, essentially pregastric, necessary in the development of piquant flavor typical of these cheeses. A simple and reproducible procedure allows us to obtain a standardized rennet paste that posses the desired activity and is of good microbiological quality. Concomitantly, a kid pregastric esterase (KPGE) was purified to homogeneity. The purification procedure was based on an aqueous extract of hygienized rennet paste (HRP), which was chromatographed on DEAE-Sepharose Fast Flow then adsorbed on phenyl superose followed by a re-chromatography on the same column. The final enzymatic preparation, where the overall activity recovery was $3 \%$, showed a molecular mass of $53 \mathrm{kDa}$. The highest activity was determined on $p$-nitrophenyl butyrate, but marked hydrolysis was also detected on $\beta$-naphthyl caprylate. In contrast, low activity on tributyrin (substrate under emulsion form) was detected, thus confirming the esterase character of purified enzyme.

(Key words: rennet paste, pregastric esterase, artisanal cheese)

Abbreviation key: KPGE = kid pregastric esterase, HRP $=$ hygienized rennet paste, $\boldsymbol{p}$-NPB $=p$-nitrophenyl butyrate, $\boldsymbol{p}$-NPC $=p$-nitrophenyl caprylate, $\boldsymbol{\beta}$-NC = $\beta$-naphthyl caprylate.

\section{INTRODUCTION}

For generations, cheesemakers from Fuerteventura (Canary Island, Spain) have utilized kid rennet paste preparations for curdling goat milk, which seems to be an essential element for the development of the unique

Received October 31, 2003.

Accepted January 7, 2004

Corresponding author: M. V. Calvo; e-mail: mcalvo@if.csic.es. organoleptic qualities detected in Majorero cheese. Rennet pastes produced by macerating the stomachs from suckling ruminants have also been used in elaboration of other traditional Spanish cheeses (Bustamante et al., 2000; Irigoyen et al., 2002) and some Italian hard cheeses varieties (Fox et al., 1993). Nevertheless, the complexity and variability of composition, depending on source (animal specie and age) and extraction mode, in addition to poor microbiological quality are the main disadvantages associated with rennet pastes produced in this traditional manner. In addition, difficulty to standardize both milk-clotting and lipase activities could represent a limitation in their use (Harboe, 1994).

Despite this drawback, rennet pastes are still used for cheeses for which a sharp, piquant flavor is desirable. This characteristic "piquant" flavor is due primarily to short-chain fatty acids resulting from the action of enzymes in the rennet paste (Rampilli and Barzaghi, 1995).

Since a liquid extract of calf oral tissue, as an alternative source of pregastric enzymes, was patented by Farnham (1950), this type of substitute has been widely employed and is now commercially available (Fox and Stepaniak, 1993). Although extensive studies have shown that their use produces satisfactory results, the connoisseurs claim that rennet paste yields superior results. Thus, there is a renewed interest in promoting the use of artisanal rennet pastes as an alternative to commercial products to maintain the authenticity of traditional cheeses as well as to impart different flavors to new products (Bustamante et al., 2000). Although it has long been recognized that pregastric enzymes play a key role and numerous attempts of characterization have been performed, the comprehensive survey of literature shows that little is known of systematic chemistry of pregastric enzymes from any mammal (O'Connor et al., 1993).

For these reasons, the aim of this work was to define a preparation procedure yielding a standardized kid rennet paste for both milk-clotting and lipase activities. In a parallel approach, the chromatographic fractionation of that hygienized rennet paste allowed the puri- 
fication of a pregastric esterase. Some structural and kinetic features of the pure enzyme are also described.

\section{MATERIALS AND METHODS}

\section{Materials}

Three batches of rennet pastes (A, B, and C) prepared by several artisanal cheesemakers of Fuerteventura (Canary Island, Spain) according to local traditional procedures from suckling kid stomachs (full of milk) were kindly donated. Prior to rennet paste preparation, the kid stomachs were sun-dried and maintained in salt (batches A and B) or were salted in brine (batch C) for at least 2 mo. Stomachs of batch $\mathrm{C}$ were also donated for the rennet paste preparation at the laboratory.

\section{Chemicals and Reagents}

Fast Garnet GBC sulphate salt, Coomasie blue R250, azocasein, tributyrin, $p$-nitrophenylbutyrate (pNPB), $p$-nitrophenylcaprylate ( $\boldsymbol{p}$-NPC), $\beta$-naphthylcaprylate $(\boldsymbol{\beta}$-NC), $\beta$-naphthol, and a gel filtration molecular weight marker kit (MW-GF-1000) were supplied by Sigma (St. Louis, MO). Diethyl amino ethyl-Sepharose Fast Flow, Phenyl Superose HR 5/5, Mono Q HR5/5, Superdex 200 HR 10/30, SDS-PAGE calibration kit, and desalting columns PD10 were purchased from Pharmacia LKB (Amersham Pharmacia Biotech, Uppsala, Sweeden). Protein assay reagent was from Bio-Rad Laboratories Inc. (Richmond, CA). Tris(hydroxymethy1)aminomethane and BSA were from Merk (Darmstadt, Germany). In the filtration process, Whatman- 1 filters from Whatman International Ltd. (Maidstone, England) and Durapore membrane filters $[0.45-\mu \mathrm{m}$ HVLP04700 and 0.22- $\mu \mathrm{m}$ GVWP04700 pore-size filter from Millipore (Bedford, MA)] were employed. Ultrafiltration cell and YM10 filters were from (Amicon Inc., Beverly, MA). All other chemicals were research grade.

\section{Preparation of Rennet Pastes and the Hygienization Process}

Kid stomachs were washed and sectioned to extract their contents, which were minced and homogenized in Milli-Q water using a Stomacher (model 400; Seward) until a semi-liquid homogeneous paste was obtained.

Water dilutions of rennet pastes $(1: 4, \mathrm{vol} / \mathrm{vol})$ were employed as starting material to perform the hygienization process. The mixtures were maintained in magnetical stirring for $16 \mathrm{~h}$ at $4^{\circ} \mathrm{C}$. The crude homogenate was first centrifuged at $15,000 \times g$ at $4^{\circ} \mathrm{C}$ for $30 \mathrm{~min}$. During centrifugation, tissue remains as well as nonsoluble particles were largely removed. The supernatant was submitted to vacuum filtration in a Millipore unit coupled to an Eyela pump (model A-3S; Tokyo Rikakikai Co.), and Whatman-1 filters were employed to eliminate particles in suspension. Subsequently, solution was filtered through $0.22-\mu \mathrm{m}$ pore-size filters (Millipore) to avoid bacterial contamination of the samples. The filtered solution was stored in either lyophilized or frozen form and kept at $-20^{\circ} \mathrm{C}$ until use.

\section{Milk-Clotting Activity and Coagulum Characteristics}

The development of milk-clotting activity and coagulum characteristics was analyzed using a model D tromboelastograph (Hellige GmbH, Freiburg, Germany). This instrument draws firmness vs. time bell-shaped graphs as clotting proceeds. The lapse of time between the addition of rennet paste and the divergence of 2 lines allow us to calculate the clotting time (r). The time in minutes from $\mathrm{r}$ until the 2 lines are $20 \mathrm{~mm}$ apart represents the rate of curd formation $\left(\mathrm{K}_{20}\right)$ and the greatest width in millimeters between both lines corresponds to curd firmness $\left(\mathrm{A}_{\max }\right)$. Fifty milliliters of $10 \%$ aqueous solution of powdered low-heat sterile milk (Nilac, The Netherlands) were equilibrated to $30^{\circ} \mathrm{C}$ for 30 min; then, $\mathrm{CaCl}_{2}$ and rennet paste solutions $(200 \mu \mathrm{L} /$ $\mathrm{mL}$ of milk) were added, and clotting parameters were determined.

\section{Rennet Strength and Cheese Yield}

Rennet strength $(\mathrm{F})$ was determined by adding $2 \mathrm{~mL}$ of water-diluted rennet (1:1) to $100 \mathrm{~mL}$ of pasteurized cow's milk, previously tempered at $35^{\circ} \mathrm{C}$. Time (in seconds) consumed until the first casein flocules occurred was controlled with a chronometer, and rennet strength was calculated by the following equation: $\mathrm{F}=240,000 / \mathrm{s}$.

The cheese yield was determined after $40 \mathrm{~min}$ of coagulation of $50 \mathrm{~mL}$ of cow's milk tempered at $30^{\circ} \mathrm{C}$ by adding $\mathrm{CaCl}_{2}(2 \%)$ and $200 \mu \mathrm{L}$ of the rennet paste extract. The curd was cut off and centrifuged at $5000 \times g$ for $10 \mathrm{~min}$, and cheese yield was calculated as the ratio between the curd's mass and the total mass of the origin milk, expressed as a percentage.

\section{Microbiological Analysis}

Sampling and dilutions were performed in accordance with International Dairy Federation standards (1985). Count of total viable microorganisms in plate count agar (Oxoid), after incubation for $72 \mathrm{~h}$ at $30^{\circ} \mathrm{C}$, was determined by the procedure previously used by Gómez et al. (1989). 


\section{Chromatographic Procedures}

All chromatographic steps were performed in a FPLC system (Pharmacia LKB, Uppsala, Sweeden) at $4^{\circ} \mathrm{C}$. Eluents were monitored at $280 \mathrm{~nm}$. Hydrolysis of $p$ NPB was used as the assay method to monitor esterase activity during purification.

The hygienized rennet paste (HRP) extract was desalted, and the buffer was changed by several washing cycles, first with Milli-Q water and subsequently with the corresponding buffer. This process was performed under refrigeration, employing an Amicon ultrafiltration cell with YM10 filters (Amicon Inc.). Once HRP was dissolved in $20 \mathrm{~m} M$ Tris. $\mathrm{HCl}$ buffer ( $\mathrm{pH} 7.5$ ), the solution $(50 \mathrm{~mL})$ was loaded onto the DEAE-Sepharose Fast Flow column XK50, equilibrated with the same buffer at a flow rate of $10 \mathrm{~mL} / \mathrm{min}$. Proteins were eluted by a nonlinear gradient using $20 \mathrm{mM}$ Tris $\cdot \mathrm{HCl}$ buffer containing $1 M \mathrm{NaCl}(\mathrm{pH} 7.5$ ) at a flow rate of $7 \mathrm{~mL} /$ $\mathrm{min}$. Those fractions containing esterase activity were pooled and concentrated by ultrafiltration; the buffer was changed to $50 \mathrm{~m} M$ sodium phosphate buffer $(\mathrm{pH}$ 7.5) containing $1.7 \mathrm{M}\left(\mathrm{NH}_{4}\right)_{2} \mathrm{SO}_{4}$. The sample was then applied onto a Phenyl Superose HR5/5 column (Pharmacia) equilibrated with the same buffer. Elution was accomplished at a flow rate of $0.25 \mathrm{~mL} / \mathrm{min}$, using a reverse linear gradient with phosphate buffer $(50 \mathrm{mM}$; $\mathrm{pH}$ 7.0). The active fractions were pooled, and because of the small resulting volume, a PD10 column (Pharmacia) was used to carry out the buffer exchange. Thereafter, that solution was rechromatographed on the Phenyl-Superose HR5/5 column. The elution conditions previously described were maintained, with the exception of a reduction in the gradient, which prevented non-desired dilutions. Lastly, some steps were repeated several times to obtain enough enzyme to allow characterization.

\section{Protein Assay}

Protein content was determined spectrophotometrically by Bradford's method (Bradford, 1976) using the Bio-Rad protein assay kit and BSA as standard.

\section{Molecular Weight Determination}

The molecular mass of purified enzyme was estimated by gel filtration (mean of 3 determinations). Chromatography was conducted on a Superdex 200 HR 10/30 column (Pharmacia), connected to an FPLC system and calibrated with a gel filtration kit (molecular weight range, 29.0 to $669 \mathrm{kDa}$ ) (Sigma Chemical Co.). The proteins were eluted using $50 \mathrm{~m} M$ sodium phosphate buffer ( $\mathrm{pH} 7.0$ ) containing $0.15 \mathrm{M} \mathrm{NaCl}$.

\section{Enzymatic Assays}

Proteolytic activity. Proteolytic activity using azocasein ( $5 \mathrm{mg} / \mathrm{mL}$ in $20 \mathrm{mM}$ sodium phosphate; $\mathrm{pH}$ 6.5) was measure at $37^{\circ} \mathrm{C}$ according to the method described by Fontecha et al. (1996). Specific activities were calculated as units per mg of protein.

Esterase activity. Esterase activity was determined employing $p$-NPB, $p$-NPC, and $\beta$-NC as substrates. For $p$-NPB, measurement was carried out by the method described by Calvo et al. (1996). Thus, $100 \mu \mathrm{L}$ of sample was added to the reaction moisture containing $800 \mu \mathrm{L}$ of Tris $\cdot \mathrm{HCl}$ buffer ( $50 \mathrm{mM}$; $\mathrm{pH} 7.5)$ and $100 \mu \mathrm{L}$ of substrate ( $8.1 \mathrm{~m} M$ in acetone). On the other hand, $p$-NPC $\left(4 \cdot 10^{-4} M\right)$ in $0.05 \mathrm{M}$ phosphate buffer $(\mathrm{pH} 7.2)$ was micellized in $0.04 M$ Triton X-100 according to Redondo et al. (1995). A volume of substrate $(2.9 \mathrm{~mL})$ previously incubated for $5 \mathrm{~min}$ at the desired temperature was mixed in the cell of the spectrophotometer (Shimadzu UV-1601; Shimadzu) with the enzyme $(100 \mu \mathrm{L})$, thereafter beginning the kinetic run. In both cases ( $p$-NPB and $p$-NPC), the enzymatic activity was measured continuously for $10 \mathrm{~min}$ at $37^{\circ} \mathrm{C}$ using a compartment of thermostatically controlled cells (model CPS-240) recording $p$-nitrophenol liberation at a wavelength of 346 $\mathrm{nm}$. One unit of enzymatic activity was defined as the enzyme amount that released a $\mu \mathrm{mol}$ of $p$-nitrophenol $\left(\varepsilon_{346}=4800 \mathrm{~L} / \mathrm{mol}\right.$ per $\left.\mathrm{cm}\right)$ per min and per $\mathrm{mg}$ of protein.

When $\beta$-NC was used as substrate, the determination was carried out by the method of Gobbetti et al. (1996). The assay mixture, containing $20 \mu \mathrm{L}$ of substrate (5 $\mathrm{mM}$ in methanol), $80 \mu \mathrm{L}$ of $0.5 M$ Tris $\cdot \mathrm{HCl}$ buffer $(\mathrm{pH}$ 7.5) and $100 \mu \mathrm{L}$ of sample, was incubated for $4 \mathrm{~h}$ at $37^{\circ} \mathrm{C}$. The reaction was stopped by addition of $360 \mu \mathrm{L}$ of Fast Garnet GBC salt (5 mg/mL in $10 \%$ SDS) and $375 \mu \mathrm{L}$ of $50 \mathrm{~m} M$ Tris $\cdot \mathrm{HCl}$ buffer ( $\mathrm{pH}$ 7.5). After centrifugation at $10,000 \times g$ for $5 \mathrm{~min}$ at $4^{\circ} \mathrm{C}$, supernatant absorbance was determined at $560 \mathrm{~nm}$ using a standard curve. The specific activity was expressed as $\mu$ moles of $\beta$-naphtol released per minute and per milligram of protein.

Lipase activity. Lipase activity against tributyrin was assayed titrimetrically by $\mathrm{pH}$-stat model PHM290 (Radiometer, Copenhagen, Denmark) with temperature regulation, which was equipped with a programmable autoburetta model ABU901 (Radiometer). The reaction mixture containing a variable tributyrin concentration $(0$ to $6 \mathrm{mM}), 0.1 \mathrm{M} \mathrm{NaCl}, 0.1 \mathrm{M} \mathrm{CaCl}_{2}$, and $1 \mathrm{~m} M$ Tris $\cdot \mathrm{HCl}$ ( $\mathrm{pH}$ 6.5) included in all cases $3 \%$ of acetonitrile as solubilizing agent (Plou et al., 1997). Rennet paste extract or pure enzyme $(250 \mu \mathrm{L})$ was added into the reaction vessel (10 $\mathrm{mL}$ of emulsion), and the reaction was monitored by titration of released carboxylic acids with standardized $\mathrm{NaOH}(10 \mathrm{~m} M)$ for 
15 min at $30^{\circ} \mathrm{C}$ and $\mathrm{pH}$ 6.4. For determining lipase activity in the 3 studied batches (before and after their processing) as well as the activity evolution in batch $\mathrm{C}$ throughout the hygienization process, only one concentration $(0.5 \mathrm{mM})$ of trybutirin was assayed. Spontaneous hydrolysis of the substrate was determined in absence of the enzymatic extract. An activity unit was defined as the amount of enzyme that releases $1 \mu \mathrm{mol}$ of fatty acid per minute and per milligram of protein.

Similarly, lipase activity of HRP using fat from cow, ewe, and goat milks as substrates was also analyzed. Thus, milk fat $(0.1 \%, \mathrm{wt} / \mathrm{vol})$ was added to an emulsion base $(10 \mathrm{~mL})$ composed of sodium caseinate $(6 \mathrm{mg} / \mathrm{mL})$ and $\mathrm{L}-\alpha$-lecithin $(1 \mathrm{mg} / \mathrm{mL})$ as has been described by Lai et al. (1997). Monitoring conditions were identical to those employed for tributyrin hydrolysis.

\section{Effect of $\mathrm{pH}$ and Temperature}

During HRP characterization, influence of $\mathrm{pH}$ (range of $\mathrm{pH}=6$ to 8 ) on lipase activity was determined at $30^{\circ} \mathrm{C}$ using cow, ewe, and goat milk fat as substrate. The effect of temperature in the range of 30 to $55^{\circ} \mathrm{C}$ was also determined at $\mathrm{pH}$ 6.4. Data were expressed as $\mu \mathrm{mol}$ of fatty acid per min and per mg of protein.

The $\mathrm{pH}$ and temperature optima for esterase activity in both rennet paste extract and purified enzyme were also examined. Thus, the effect of $\mathrm{pH}$ (range $=4$ to 10) at $37^{\circ} \mathrm{C}$ as well as the influence of temperature (in the range 5 to $\left.55^{\circ} \mathrm{C}\right)$ in $\mathrm{Tris} \cdot \mathrm{HCl}(50 \mathrm{mM} ; \mathrm{pH} 7.0)$ were analyzed. In both cases, $p$-NPB was used as substrate. Data are means of 3 lectures, and results were expressed as a percentage of maximum activity.

\section{Curve Fitting of Experimental Data}

Hyperbolic kinetics were analyzed using the MMFIT iterative program of the SIMFIT package (Bardsley, 1993). The program performs weighted nonlinear regression to the Michaelis-Menten equation and gives the corresponding table with the parameter values and their statistical confidence limits.

\section{RESULTS AND DISCUSSION}

\section{Rennet Pastes Processing}

Use of rennet pastes in artisanal elaboration of Majorero cheese, as both coagulating activity and lipase source, is still common in Fuerteventura Island (Spain). The heterogeneous composition of rennet pastes as well as their poor microbiology can place restrictions on their correct use and, therefore, make an accurate analytical control mandatory (Rampilli and Barzaghi, 1995).
For this reason, a technological process was designed in our laboratory to obtain a hygienized rennet paste showing the peculiarities of those elaborated in artisanal manner. Three batches of kid rennet paste, designated as A, B, and C and prepared in artisanal manner for several cheesemakers, were processed following a general purification scheme, whose early steps were focused on the removal of non-soluble compounds from the crude starting material. Thus, their suitable processing included extraction, homogenization, centrifugation, and filter-sterilization.

Factors such as origin and method of storage of pregastric tissues have been recently analyzed (Bustamante et al., 2000) to determine their influence on coagulating and lipolytic activities in rennet pastes. This is an important issue as previously pointed out by De Caro et al. (1995), as different yields were obtained depending on the starting material employed.

Once the rennet pastes were processed as described, a comparative study of enzymatic activities and analysis of the presence of microorganisms was performed. One of the most critical concern with the use of rennet pastes in cheesemaking is their poor microbiological quality. Evaluation of microbial flora present in batches $\mathrm{A}, \mathrm{B}$, and $\mathrm{C}$ indicated that number of viable cells was of $5.4,6.1$, and $3.4 \mathrm{log} \mathrm{cfu} / \mathrm{g}$, respectively, decreasing drastically until becoming nonnegligible at the end of the cleanly process.

Figure 1 summarizes data of esterase (1A), lipase (1B), and proteolytic (1C) activities determined in the 3 batches (before and after their processing). As expected, different results, depending on paste origin, were obtained, although in most cases slight decreases in the studied activities took place during the process. This fact could be explained partly because of the loss of enzymatic activity (either in centrifugation pellet and/ or adsorbed onto filtration membranes), an inherent phenomenon associated with processes such as these, as well as by microorganism removal. There appears not to be significant differences with respect to tributyrin hydrolysis among the 3 batches of rennet paste (Figure 1B), as the recovery of lipase activity was $>82 \%$ in all cases. It is interesting to note that batch $\mathrm{C}$ showed the highest esterase activity and good yield (75\%) with regard to activity recovery. This fact, along with the satisfactory levels of tributyrin hydrolysis detected, might be a technological advantage because of the implication of both activities in short-chain fatty acid formation and the important contribution of these compounds to cheese flavor developing (Fox et al., 1993). To the contrary, this paste presented the lowest proteolytic activity, probably because of the limited presence of bacterial soluble proteinases, which can be explained by the low microbiological contamination detected, as 

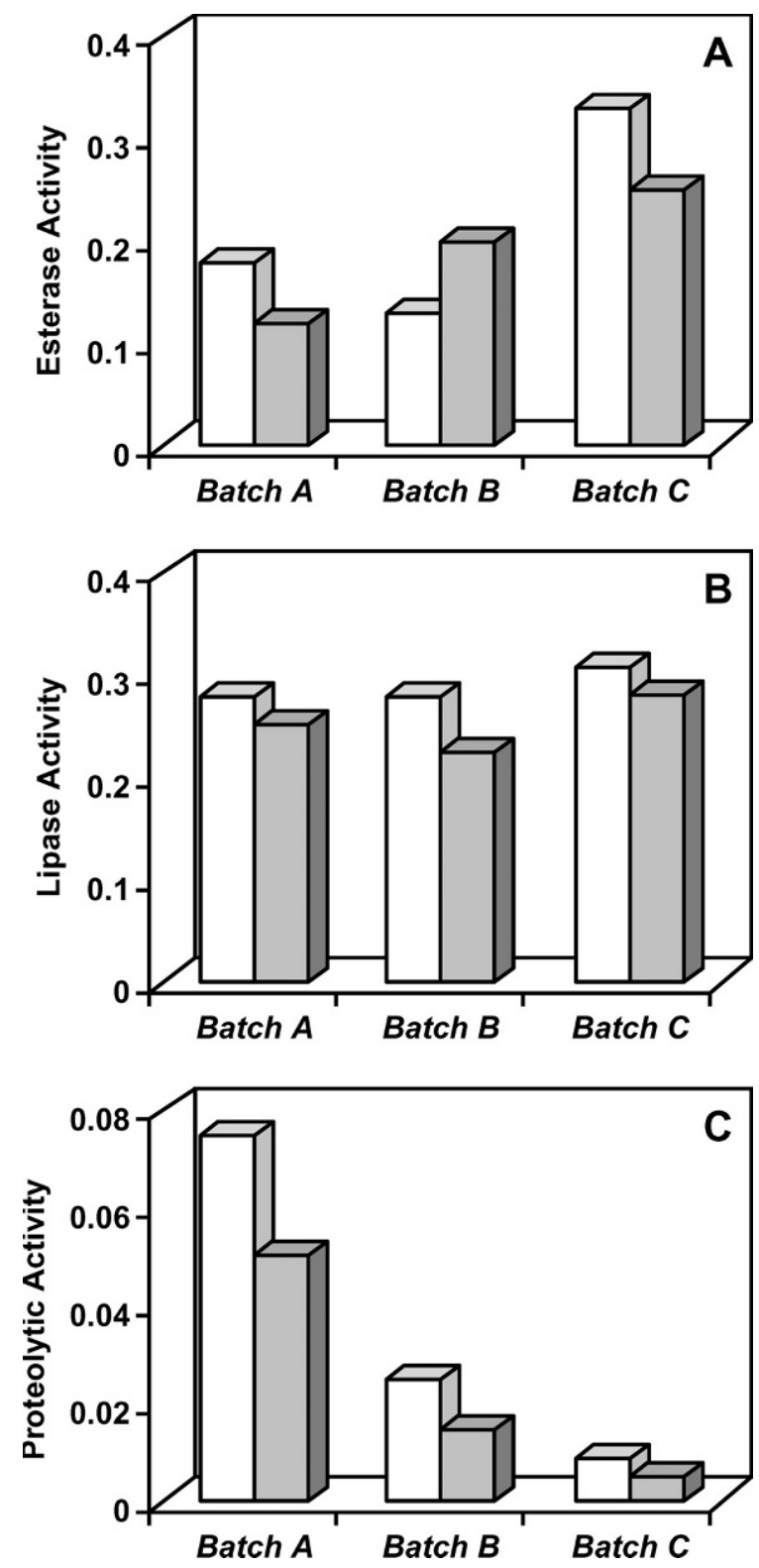

Figure 1. Comparative study of 3 artisanal rennet pastes designated as Batches A, B, and C. Esterase activity, employing $\beta$-naphthyl caprylate as a substrate (A); lipase activity, using tributyrin (B); and proteolytic activity against azocasein $(\mathrm{C})$ were determined. Open bars $=$ crude homogenate, and solid bars $=$ hygienized rennet paste . Activities are expressed as units/mg.

was previously pointed out. Thus, because of its marked esterase and lipase activities as well as its better microbiological quality, batch $\mathrm{C}$ was chosen to carry out a further characterization.

\section{Characterization of the Rennet Paste (Batch C)}

To analyze reproducibility and reliability of the process employed, batch $\mathrm{C}$ was divided into 4 identical lots that were submitted to the hygienization process simultaneously. In Table 1, some parameters analyzed for $\mathrm{C}$ rennet paste characterization, as well as their evolution through the different stages of the processing (crude homogenate, centrifuged, and filtered paste), are summarized. Data represent the means of values corresponding to the 4 lots from $\mathrm{C}$ rennet paste.

Primarily, the influence of the hygienization process on the technological aptitude of $\mathrm{C}$ rennet paste was analyzed. As can be deduced from the parameters collected in Table 1, the coagulating power of the rennet paste was not affected by the process, and the coagulation time was even shortened slightly, which can be related to higher specific clotting activity. Variation of rennet strength and cheese yield were also determined, as was relevant data from a cheesemaking point of view. Rennet strength increased lightly, probably because of an optimum solubilization of clotting enzymes, although it was 10 -fold lower than that corresponding to the control. Cheese yield of rennet paste was also lower than that of commercial rennet paste but increased through the hygienization process.

Concerning esterase, lipase, and proteolytic activities, as has been described previously for analysis of rennet pastes from different sources, a slight decrease in all activities during the hygienization process was detected. Approximately, $76 \%$ of initial proteolytic activity from crude homogenate was recovered in filtrate. With regard to esterase and lipase activities, a yield of 73 and $90 \%$, respectively, was achieved. This is a good result when compared with $20 \%$ lipase activity recovery reported by De Caro et al. (1995) during cleanliness of an extract from lamb pharingeal tissues.

Subsequently, the lipase activity using ewe, goat, and cow milk fat as substrates was uniquely determined on the hygienized fraction of $\mathrm{C}$ rennet paste. Qualitative composition of fatty acids from ewe milk is similar to cow and goat milk, but quantitative differences between them are also observed. Cow milk has a higher proportion of high molecular weight triglycerides and unsaturated free fatty acids; otherwise, ewe and goat milk have higher quantities of short- and medium-chain fatty acids (Ruiz-Sala et al., 1996). Harper (1955) was the first to establish that pregastric enzymes preferentially release short-chain fatty acids from milk fat and published extensively on characteristics of the lipolytic systems in rennet pastes from different sources and their role in Italian-type cheese. Long and Harper (1956) reported that desirable flavor development in both Romano and Provolone cheeses was related directly to butyric acid content, and this was dependent upon the enzyme source employed. More recently, $\mathrm{Ha}$ and Lindsay (1993) demonstrated that pregastric enzymes exhibited selectivity for hydrolysis of volatile 
Table 1. Evolution of technological parameters as well as esterase, lipase, and proteolytic activities of artisanal C rennet paste through the different stages of hygienization rennet paste processing. Values are the means corresponding to the 4 replicates (lots) of the rennet paste (Batch C). Standard deviations are also included.

\begin{tabular}{|c|c|c|c|c|c|c|c|c|}
\hline Rennet paste & $\begin{array}{l}\text { Rennet } \\
\text { strength }\end{array}$ & $\begin{array}{l}\text { Cheese } \\
\text { yield }\end{array}$ & $\begin{array}{l}\text { Coagulation } \\
\text { time }\end{array}$ & $\begin{array}{l}\text { Specific } \\
\text { clotting } \\
\text { activity }^{1}\end{array}$ & $\mathrm{~K}_{20}$ & $\begin{array}{l}\text { Specific } \\
\text { esterase }^{\text {activity }}{ }^{2}\end{array}$ & $\begin{array}{l}\text { Specific } \\
\text { lipase } \\
\text { activity }^{3}\end{array}$ & $\begin{array}{l}\text { Specific } \\
\text { proteolytic } \\
\text { activity }^{4}\end{array}$ \\
\hline & & $(\%)$ & $(\min )$ & & $(\mathrm{cm})$ & & & \\
\hline Centrifuged paste & $1: 9.000$ & 9.80 & 1.5 & 2.66 & 13 & $0.74 \pm 0.02$ & $0.83 \pm 0.01$ & $0.018 \pm 0.002$ \\
\hline Filtered paste $^{5}$ & $1: 10.000$ & 10.03 & 1.5 & 2.66 & 11 & $0.68 \pm 0.01$ & $0.79 \pm 0.01$ & $0.025 \pm 0.002$ \\
\hline Control rennet ${ }^{6}$ & $1: 126.000$ & 16.05 & $\mathrm{ND}^{7}$ & ND & ND & $\mathrm{ND}$ & ND & ND \\
\hline
\end{tabular}

${ }^{1}$ One unit $=1 / \mathrm{t}$, where $\mathrm{t}$ is defined as time $(\mathrm{min})$ consumed for coagulating $1 \mathrm{~mL} \mathrm{milk} / \mathrm{mg}$ protein.

${ }^{2}$ Expressed as $\mu \mathrm{mol}$ of $\beta$-naphthol released from $\beta$-naphthyl caprylate per min and per mg of protein.

${ }^{3}$ Expressed as $\mu \mathrm{mol}$ of butyric acid released from tributyrin per min and per mg of protein.

${ }^{4}$ Expressed in increments of 0.1 absorbance units at $440 \mathrm{~nm}$ per min and per $\mathrm{mg}$ of protein.

${ }^{5}$ Hygienized rennet paste.

${ }^{6}$ Commercial powered rennet (Chr. Hansen) was used as the control.

${ }^{7} \mathrm{ND}=$ not determined.

branched-chain and short n-chain fatty acids and for $s n-1$ and $s n-3$ position on glycerides.

Our results indicated that hygienized rennet paste exhibited similar lipase activity levels independently of the source of analyzed milk fat. Nevertheless, we found that lipase activity was slightly higher with ewe milk fat $(0.017 \mu \mathrm{mol}$ fatty acid/min per $\mathrm{mg})$ than with cow or goat milk fat $(0.015$ and $0.014 \mu \mathrm{mol}$ fatty acid/ min per $\mathrm{mg}$, respectively).

Similarly, the effect of temperature and $\mathrm{pH}$ on lipase activity was analyzed (data not shown). Unremarkable differences in behavior of purified rennet paste against milk fat from the 3 species were detected, showing enough activity on a wide range of temperatures. Optimum temperature was in the range between 40 and $45^{\circ} \mathrm{C}$ for cow and goat milk fat and near $40^{\circ} \mathrm{C}$ for ewe milk fat. Broad ranges of optimum temperatures have also been described for partially purified lipases of kid and goat (Lai et al., 1997) and lamb (Barton et al., 1996) obtained from commercial preparations. The $\mathrm{pH}$ optimum for lipase activity determined at $30^{\circ} \mathrm{C}$ ranged from 6.4 to 6.8 , and similar profiles were obtained for all substrates. Below $\mathrm{pH}$ 6, precipitation of the caseinate component of the emulsion occurs (Barton et al., 1996); therefore, measurements under cheese-ripening conditions were not feasible. At $\mathrm{pH}>7.0$, all 3 milk fats analyzed displayed an identical trend; remaining lipase activity was almost constant around $0.015 \mu \mathrm{mol}$ fatty $\mathrm{acid} / \mathrm{min}$ per $\mathrm{mg}$.

Similar optimum $\mathrm{pH}$ values have been observed in pure lipases from kid (Lai et al., 1998), lamb (De Caro et al., 1995), and calf (Bernbäck et al., 1985).

Once homogeneity concerning the properties of the resulting products was verified, the 4 hygienized lots from batch $\mathrm{C}$ were pooled. Thus, enough rennet paste with well-defined characteristics and a good microbio- logical quality was achieved. The filtrate was labeled as HRP and was stored in either lyophilized or frozen form and kept at $-20^{\circ} \mathrm{C}$ until use.

Although in a first approach pre-elaborated $\mathrm{C}$ rennet paste was employed, another experiment was also performed in parallel using kid stomachs (supplied by the same cheesemaker). Their processing in the laboratory was identical to that employed for artisans in $\mathrm{C}$ rennet paste elaboration. Similar results were obtained in both cases, thus confirming reproducibility and reliability of hygienization process as described previously.

In light of these results, one might conclude that the hygienization process has successfully overcome the problems associated with the use of artisanal rennet paste. The final product retained enough clotting and esterase/lipase activities and showed an improved microbiological quality with respect to crude rennet paste. This fact contributes to development of curd characteristics and release of typical flavor of the cheeses that use rennet paste in their elaboration process. On the contrary, the low cheese yield should be considered for the further study in cheese manufacture. Perhaps to overcome this drawback, the use of mixtures containing both artisanal rennet paste, providing the organoleptic features of this kind of cheese, and commercial rennet to accelerate the coagulation process may be a feasible alternative from the industrial point of view. With respect to lipase activity against goat, ewe, and cow milk fat, $\mathrm{C}$ rennet paste extract showed similar trends, and it appeared to have optimum activity at $\mathrm{pH}$ and temperature values closer to manufacture conditions than to ripening conditions.

\section{Kid Pregastric Esterase Purification}

Crude rennet paste contains large quantities of nonsoluble components, and this raw material does not 
lend itself to reproducible purification experiments. For this reason, HRP was used as starting material in order to carry out chromatographic fractionation.

Figure 2 shows elution profiles of the 3 chromatographic steps finally chosen. First, an ultrafiltration process was employed to perform desalting and sample buffer exchange. Subsequently, the HRP solution obtained was loaded onto a DEAE-Sepharose Fast Flow column (Figure 2A). Active fractions were eluted at a concentration of around 400 to $500 \mathrm{mM} \mathrm{NaCl}$ and were recovered as a single peak. Similar results were reported by Lai et al. (1998) for the main protein peak during goat pregastric lipase purification. Interestingly, active fraction that was recovered from the DEAE-Sepharose Fast Flow column had lost clotting activity. Nevertheless, esterase activity $(1.69 \mathrm{U} / \mathrm{mg})$ was clearly increased (2-fold higher than for HRP [0.93 $\mathrm{U} / \mathrm{mg}])$. On the other hand, proteolytic activity (0.028 $\mathrm{U} / \mathrm{mg}$ ) was similar to that detected in crude rennet paste $(0.033 \mathrm{U} / \mathrm{mg})$.

Ongoing with enzyme purification, active fractions were pooled and concentrated. After desalting and exchanging buffer, this solution was chromatographed on Phenyl Superose HR 5/5 (Figure 2B). The esterase activity (eluted at 0.25 to $0 M$ ) was detected at the end of the $\left[\mathrm{NH}_{4}\right]_{2} \mathrm{SO}_{4}$ gradient, thus indicating the high hydrophobicity of enzyme. At this stage of the purification process, 2 alternative chromatographic pathways were assayed. The first consisted of a Mono Q HR5/5 column equilibrated with Tris $\cdot \mathrm{HCl}(20 \mathrm{~m} M ; \mathrm{pH} 7.5)$. Proteins were eluted by a linear gradient (from 0 to 0.35 $\mathrm{M} \mathrm{NaCl}$ ) at a flow rate of $1 \mathrm{~mL} / \mathrm{min}$. As no substantial improvement in purification yield was achieved (data not shown), its use was definitely ruled out. Finally, a rechromatography of active fraction on the same Phenyl-Superose HR5/5 column (Figure $2 \mathrm{C}$ ) yielded the purified enzyme. Sometimes a second run of the same type of column was necessary to obtain homogeneous kid pregastric esterase (KPGE).

Table 2 shows a representative enzyme purification flowsheet. The chromatographic yields with DEA-Sepharose Fast Flow, Phenyl Superose (I), and Phenyl Superose (II) were 69,51 , and $5.7 \%$, respectively. A final 308 -fold purification was achieved from the hygienized rennet paste with an overall enzymatic recovery of $6 \%$. From $250 \mathrm{~mL}$ of HRP, about $150 \mu \mathrm{g}$ of pure enzyme were achieved. The enzyme solution can be stored several months at $-20^{\circ} \mathrm{C}$ without any noticeable loss of catalytic activity.

\section{KPGE Characterization}

For a long time, pregastric enzymes have been studied and purified from pharyngeal tissues (O'Connor et
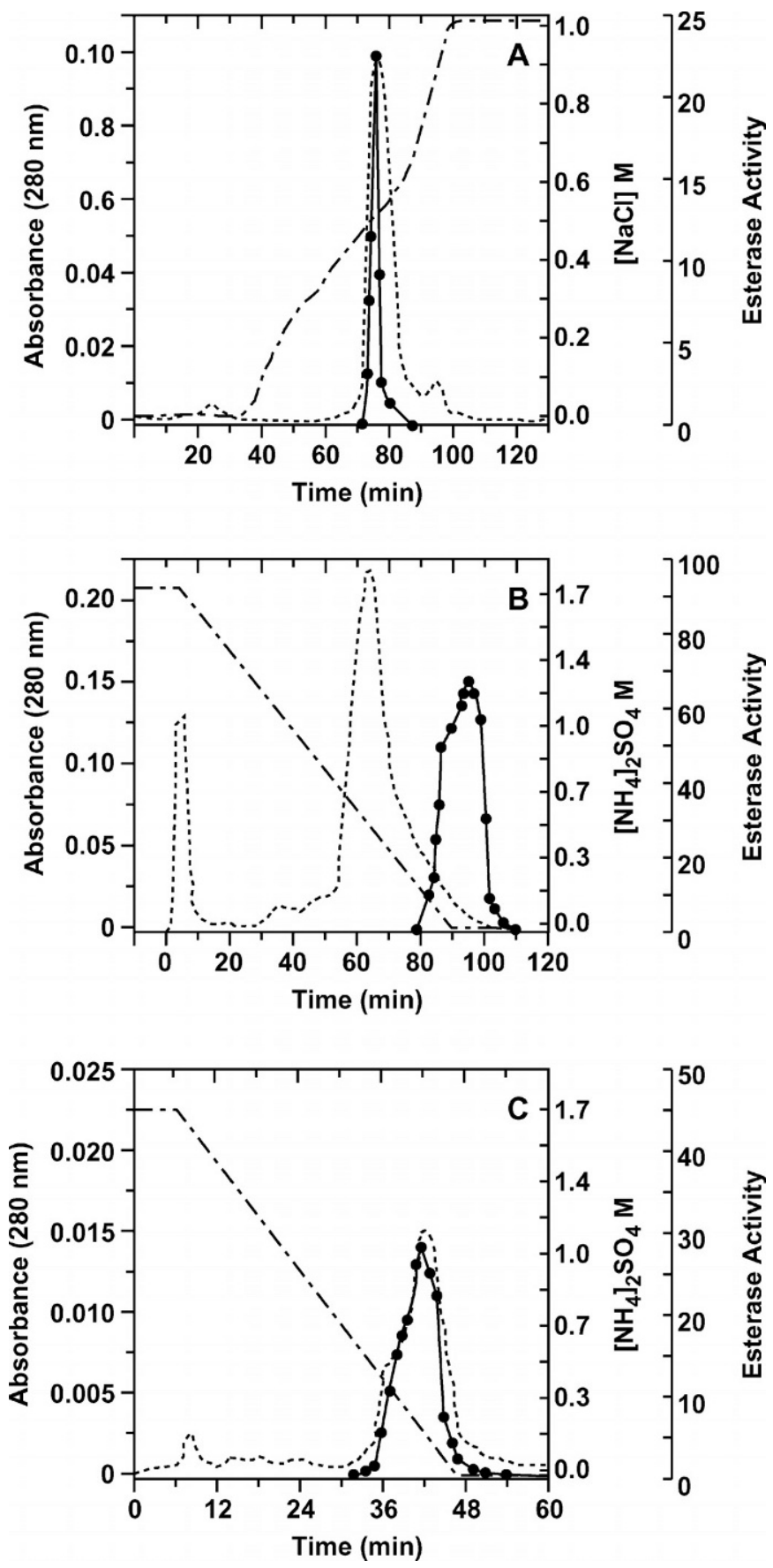

Figure 2. Purification profiles: A) ion-exhange chromatography on DEAE-Sepharose Fast Flow, B) phenyl Superose chromatography I, and C) phenyl Superose chromatography II. Esterase activity was measured using $p$-nitrophenyl butyrate as a substrate (- - ). Absorbance at $280 \mathrm{~nm}$ is represented with a dashed line; the corresponding gradient is represented by --- .

al., 1993; De Caro et al., 1995; Villeneuve et al., 1996) or commercial preparations (Richardson and Nelson, 1967; D’Souzza and Oriel, 1992; Barton et al., 1996). Most literature studies have characterized the activity 
Table 2. Flowsheet for the purification of kid pregastric esterase (KPGE).

\begin{tabular}{llllll}
\hline Purification step & $\begin{array}{l}\text { Total } \\
\text { activity }\end{array}$ & $\begin{array}{l}\text { Total } \\
\text { protein }\end{array}$ & $\begin{array}{l}\text { Specific } \\
\text { activity }^{1}\end{array}$ & $\begin{array}{l}\text { Activity } \\
\text { recovery }\end{array}$ & $\begin{array}{l}\text { Purification } \\
\text { factor }\end{array}$ \\
\hline Hygienized rennet paste & $(\mathrm{U})$ & $(\mathrm{mg})$ & $(\mathrm{U} / \mathrm{mg})$ & $(\%)$ & \\
Fast Flow DEAE-Sepharose & 32 & 200 & 0.04 & 100 & 1 \\
Phenyl Superose (I) & 20.7 & 22.5 & 0.92 & 69 & 23 \\
Phenyl Superose (II) & 16.3 & 8.4 & 1.94 & 51 & 48.5 \\
\hline
\end{tabular}

${ }^{1}$ Specific activity was measured using $p$-nitrophenyl butyrate as a substrate.

in crude or partially purified preparations; hence, the considerable variation in data reported makes difficult any attempt to state clearly the properties of these pregastric enzymes.

In this work, we describe some features of the KPGE previously isolated. The molecular mass estimated by FPLC gel filtration on a Superdex 200 HR10/30 column was $53 \mathrm{kDa}$. This apparent molecular weight was similar to those reported for calf (Bernbäck et al., 1985) and lamb (De Caro et al., 1995) lipases.

The $\mathrm{pH}$ and temperature profiles (Figure 3 ) showed only slight differences in HRP and KPGE behavior against both factors. Thus, the pure enzyme remained active in a abroad range of $\mathrm{pH}$ values (Figure 3A), locating optimum activity at $\mathrm{pH}$ 7.5. On the other hand, HRP exhibited optimum at $\mathrm{pH} 7$, being little bit more active than pure esterase at lower $\mathrm{pH}$ values. Concerning temperature (Figure 3B), although HRP was perfectly stable from 40 to $45^{\circ} \mathrm{C}$, KPGE had the optimum temperature at $37^{\circ} \mathrm{C}$ and then its enzymatic activity rapidly decreased reaching $10 \%$ of its initial value at $50^{\circ} \mathrm{C}$. Contrary, HRP kept $56 \%$ of the maximum activity at that temperature. These data were in good agreement with those reported by Richardson (1967). Taking into consideration the results for $\mathrm{pH}$ and temperature, it could be speculated that the addition of hygienized rennet pastes do not contribute significantly to the release fatty acids during cheese ripening. Nevertheless, because the $\mathrm{pH}$ and temperature of milk when the rennet paste is added are close to the optimum for KPGE, the enzyme would preferentially act during milk coagulation and cheesemaking.

\section{Substrate Specificity}

Most previous studies on pregastric enzymes have been carried out with crude preparations or commercial extracts, and there exit only few kinetic and biochemical data on purified enzyme. To determine whether HRP and KPGE exhibit different substrate specificity, a study on hydrolysis of different compounds was performed.

First, esterase activity on $p$-NPB, $p$-NPC, and $\beta$-NC was determined at $37^{\circ} \mathrm{C}$. Molecular structures of the assayed compounds as well as the specific activities (mean of 3 replicates) for HRP and KPGE are shown in Table 3. It is noteworthy that HRP showed a very low activity against $p$-NPB $(0.04 \mathrm{U} / \mathrm{mg})$; its activity was 4 - and 22 -fold higher for $p$-NPC and $\beta$-NC, respectively.
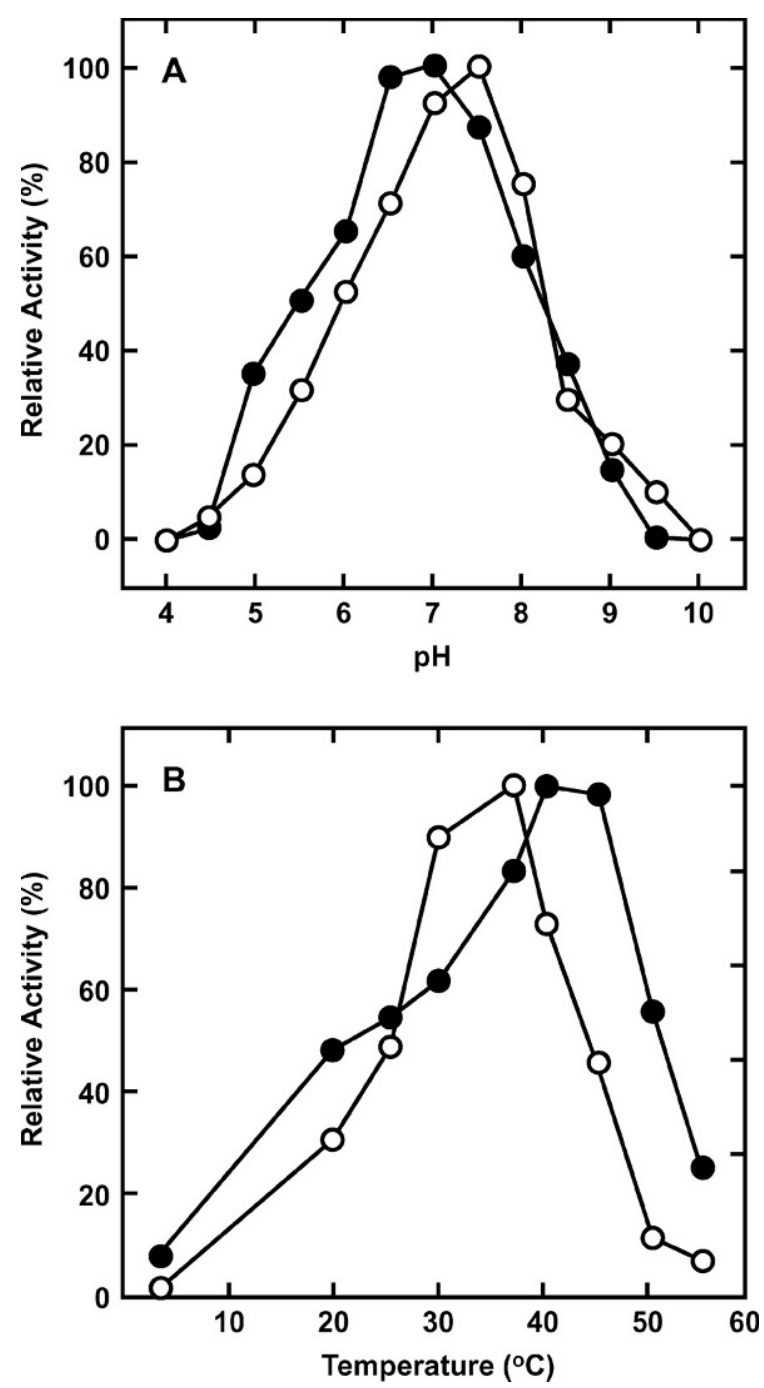

Figure 3. Effect of $\mathrm{pH}(\mathrm{A})$ and temperature (B) on esterase activity using $p$-nitrophenyl butyrate as a substrate; both hygienized rennet paste $(\bullet)$ and kid pregastric esterase $(\bigcirc)$ are presented. 
Table 3. Substrate specificity of HRP and KPGE. Esterase activity was determined using $\beta$-NC, $p$-PNC, and $p$-PNB as substrates.

\begin{tabular}{l} 
Specific activity (U/mg) \\
\cline { 2 - 3 }
\end{tabular}

In contrast, $p$-NPB was the best substrate for pure enzyme, detecting a specific activity of $12.3 \mathrm{U} / \mathrm{mg}$. Nevertheless, an unexpected low activity toward $p$-NPC (15fold lower than on $p$-NPB) was found. Although, both substrates show quite similar structures, the length of fatty acid chain (C4 or C8) attached on its molecule seems to determine enzyme behavior. As previously pointed out by O'Connor et al., (1996), the effect of increasing the carbon chain length not only changes the hydrophobic nature of the ester, but also changes the size and the shape of the substrate. This finding should not only be attributed to the length of fatty acid chain but also to micellization of $p$-NPC with Triton X100 , as this system mimics, to a certain extent, an emulsion.

Taking into account that KPGE exhibited maximum activity for butyric acid, we decided to analyze its behavior when this fatty acid was attached on a triglyceride molecule. Thus, a kinetic study of lipolytic activity with tributyrin (a typical substrate employed normally to determine lipase activity) was also carried out. A hyperbolic saturation curve of Michaelis-Menten type was obtained for both samples in the tributyrin hydrolysis (Figure 4). It is known that enzymes acting at interface cannot be treated by classical Michaelis-Menten theory because of the 2-dimensional state of substrate involved. Therefore, the $\mathrm{K}_{m}$ and $\mathrm{V}_{\max }$ parameters do not have the usual mechanistic meaning but rather a more complex one (Martinelle and Hult, 1994). Thus, they are used with a superscript ${ }^{a p p}$ to take into account such peculiarities. Results were analyzed by non-linear regression methods (Barsdley, 1993). Surprisingly, both HRP and KPGE display the same qualitative behavior, although there are large quantitative differences between them.

In the inset table of Figure $4, K_{m}{ }^{a p p}$ and $K_{c a t}{ }^{a p p}$ values, as well as the specificity constant, are reported. As can be observed, the $K_{m}{ }^{a p p}$ value for HRP was 190 -fold lower than that found for KPGE, which means that rennet paste has a higher affinity for tributyrin under experimental conditions. Regarding the $K_{c a t}{ }^{a p p} / K_{m}{ }^{a p p}$ ratios, the high specificity constant of HRP is due mainly to the low $K_{m}{ }^{a p p}$ value, as the catalytic constant is only 2fold higher than that corresponding to KPGE. Such specificity was similar to that reported by O'Connor et al. (1993) for lamb pregastric lipase.

Hence, KPGE turns out to be quite specific for butyric acid when found under the form of ester in solution, and activity is reduced drastically when substrate appears under the form of tributyrin emulsion. This result is in agreement with the enzyme behavior toward $p$-NPC micellized with Triton X-100 as described previously.

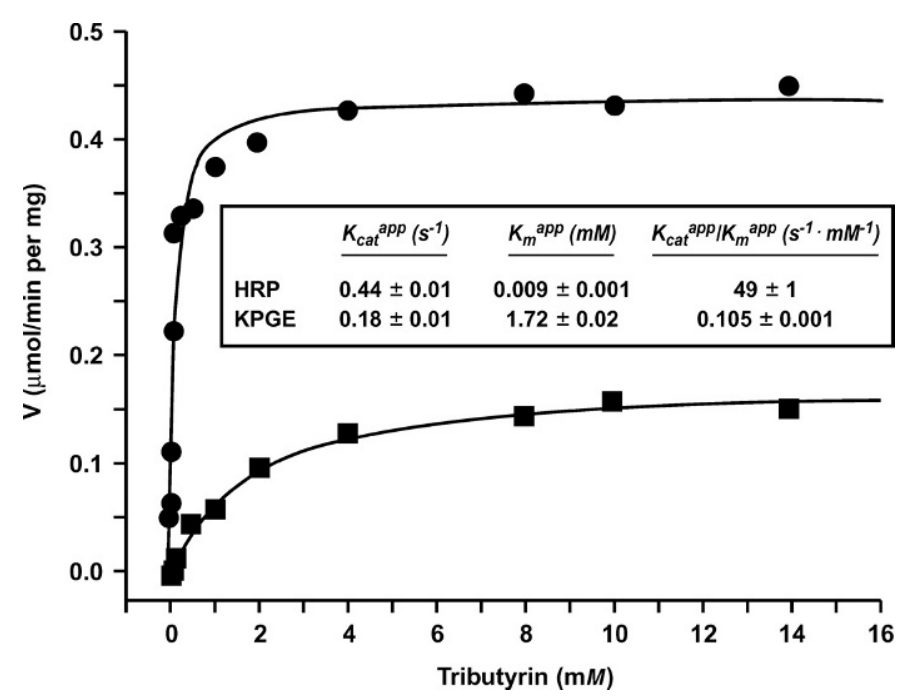

Figure 4. Hyperbolic saturation curves for hydrolysis of tributyrin at $\mathrm{pH} 6.7$ and $30^{\circ} \mathrm{C}$ using hygienized rennet paste (HRP; $)$ and kid pregastric esterase (KPGE; $\mathbf{\square})$. The inset table summarizes Michaelis-Menten parameters for both samples. 
Despite the high hydrophobicity shown during its purification, these results clearly denote that KPGE presents an esterase character, as if it would be a lipase, and the enzyme would have to be activated in the presence of an interface (Desnuelle and Savary, 1963).

This is a good finding in the sense that it suggests the action mode of the isolated enzyme. The KPGE showed specificity for butyric acid, thus contributing to the development of the typical flavor of Majorero cheese. This very marked short-chain specificity of KPGE might be an advantage in dairy industry. As previously mentioned, short-chain fatty acids contribute to a large extent in the cheese flavor development, because of their very volatile character and also because they are precursors of other aromatic compounds.

The marked differences concerning substrate specificity between HRP and KPGE had no simple explanation. Probably, kid gastric extract would be an heterogeneous mixture, where several enzymes are present and show superimposed activities. Traditional rennet paste is expected to contain both esterase(s) and lipase(s), the origins of which could be pregastric but could also be caused by microbial flora contamination during stomach maceration (Nelson et al., 1977).

\section{CONCLUSIONS}

Because of the lack of a standardized preparation procedure yielding rennet pastes of consistent quality, their use has been gradually avoided by cheese manufacturers. In present work, a technological process, simple and reproducible, was designed to obtain an HRP. This product could represent an interesting alternative to those now available in the market, as it not only exhibited an improved microbial quality but also retained the peculiarities of the rennet pastes elaborated in artisanal manner. On the other hand, the chromatographic fractionation of that HRP allowed us to isolate a pure enzyme (KPGE) that showed an estimated molecular mass of $53 \mathrm{kDa}$. It is likely that we actually purified an esterase with some structural characteristics in common with other pregastric enzymes described in literature, but differing in its substrate specificity. The enzyme displayed different degrees of activity against different esters, depending on the number of carbon atoms of hydrocarbon tail and the physical presentation of the substrate (micelles or simple aqueous solution). Moreover, low activity toward tributyrin was detected. All results contribute to a better knowledge of the rennet paste properties and their role during cheese elaboration and ripening.

\section{ACKNOWLEDGMENTS}

This research was carried out with the financial support of Cabildo Insular de Fuerteventura, Spain. The authors are grateful to D. Casto Berriel Martínez and D. Marino García Jaquete (Servicio de Agricultura, Ganadería y Pesca del Cabildo Insular de Fuerteventura, Spain) for their support in development of this project and for generously supplying stomachs and rennet pastes from kids. M. V. Calvo thanks Gobierno Vasco for a postdoc fellowship.

\section{REFERENCES}

Bardsley, G. W. 1993. SIMFIT: A Package for Simulation, CurveFitting and Statistical Analysis in the Life Sciences. Manchester University, UK.

Barton, R. H., C. J. O’Connor, and K. W. Turner. 1996. Characteristics of tributyroylglycerol hydrolysis mediated by a partially purified lamb pregastric lipase. J. Dairy Sci. 79:27-32.

Bernbäck, S., O. Hernell, and L. Bläckberg. 1985. Purification and molecular characterization of bovine pregastric lipase. Eur. J. Biochem. 148:233-238.

Bradford, M. M. 1976. A rapid and sensitive method for the quantitation of microgram quantities of proteins utilizing the principle of protein-dye binding. Anal. Biochem. 72:248-254.

Bustamante, M., F. Chávarri, A. Santisteban, G. Ceballos, I. Hernandez, M. Jose Miguelez, I. Aramburu, L. J. R. Barrón, M. Virto, and M. de Renobales. 2000. Coagulating and lipolytic activities of artisanal lamb rennet pastes. J. Dairy Res. 67:393-402.

Calvo, M. V., F. J. Plou, and A. Ballesteros. 1996. Effect of surfactants on activity and stability of native and chemically modified lipases A and B from Candida rugosa. Biocatal. Biotrans. 13:271-285.

D’Souzza, T. M., and P. Oriel. 1992. Purification and characterization of lamb pregastric lipase. Appl. Biochem. Biotechnol. 36:183-198.

De Caro, J., F. Ferrato, R. Verger, and A. De Caro. 1995. Purification and molecular characterization of lamb pregastric lipase. Biochim. Biophys. Acta 1252:321-329.

Desnuelle, P., and P. Savary. 1963. Specificities of lipases. J. Lipid Res. 4(4):369-384.

Farnham, M. G. 1950. Cheese modifying enzyme products. U.S. Patent $2,531,329$.

Fontecha, J., T. Requena, and H. E. Swaisgood. 1996. Affinity chromatography of proteinases using bacitracin immobilized to porous glass beads. Lett. Appl. Microbiol. 22:371-374.

Fox, P. F., J. Law, P. H. L. McSweeney, and J. Wallace.1993. Biochemistry of cheese ripening In Cheese: Chemistry, Physics, and Microbiology. Vol. I. P. F. Fox, ed. Chapman \& Hall, London, England.

Fox, P. F., and L. Stepaniak. 1993. Enzymes in cheese technology. Int. Dairy J. 3:509-530.

Gobbetti, M., P. F. Fox, and L. Stepaniak. 1996. Esterolytic and lipolytic activities of mesophilic and thermophilic lactobacilli. Italian J. Food Sci. 8:127-135.

Gómez, R., C. Peláez, and E. de la Torre. 1989. Microbiological study of semi-hard goat's milk cheese (Majorero). Int. J. Food Sci. Technol. 24:147-151.

Ha, J. K., and R. C. Lindsay. 1993. Release of volatile branched-chain and other fatty acids from ruminant milk fats by various lipases. J. Dairy Sci. 76:677-690.

Harboe, M. K. 1994. Use of lipases in cheesemaking. Pages 11-16 in Bull. Int. Dairy Fed. Vol. 294. IDF, Brussels, Belgium.

Harper, W. J. 1955. Apparent selective liberation of butyric acid from milk fat by the action of various lipase systems J. Dairy Sci. 38:1391-1398.

International Dairy Federation. 1985. Milk and milk products. Methods of sampling. FIL-IDF 50B. IDF, Brussels, Belgium.

Irigoyen, A., J. M. Izco, F. C. Ibañez, and P. Torre. 2002. Influence of calf or lamb rennet on the physicochemical, proteolytic and sensory characteristics of an ewe's-milk cheese. Int. Dairy J. 12:27-34.

Lai, D. T., A. D. Mackenzie, C. J. O'Connor, and K. W. Turner. 1997. Hydrolysis characteristics of bovine milk fat and monoacid triglyc- 
erides mediated by pregastric lipase from goats and kids. J. Dairy Sci. 80:2249-2257.

Lai, D. T., D. R. Stanley, and C. J. O'Connor. 1998. Purification of pregastric lipases of caprine origin. J. AOCS 75:411-416.

Long, J. E., and W. P. Harper. 1956. Italian cheese ripening VI. Effects of different types of lipolytic enzyme preparations on acumulation of various free fatty and free amino acids and the development of flavour in Provolone and Romano cheese. J. Dairy Sci. 39:245-252.

Martinelle, M., and K. Hult. 1994. Kinetics of triglyceride lipases. Pages 159-180 in Lipases, Their Structure, Biochemistry, and Application. P. Woodley and S. B. Petersen, ed. Cambridge University Press, Cambridge.

Nelson, J. H., R. G. Jensen, and R. E. Pitas. 1977. Pregastric esterase and other oral lipases-A review. J. Dairy Sci. 60:327-362.

O'Connor, C. J., D. T. Lai, and K. W. Barton. 1996. Lamb pregastric enzyme-catalysed hydrolysis of 4-nitrophenylalkanoates and monoacid triglycerides. J. Mol. Catal. B 1:143-149.

O'Connor, C. J., R. D. Manuel, and K. W. Turner.1993. Calf and lamb lingual lipases as catalysts for the hydrolysis of tributyrin, triolein and 4-nitrophenylacetate. J. Dairy Sci. 76:3674-3682.
Plou, F. J., P. Sogo, M. V. Calvo, F. J. Burguillo, and A. Ballesteros. 1997. Kinetic and enantioselective behaviour of isoenzymes A and B from Candida rugosa lipase in the hydrolysis of lipids and esters. Biocatal. Biotrans. 15:75-89.

Rampilli, M., and S. Barzaghi. 1995. The rennet paste: Some analytical aspects. Il Latte 5:517-521.

Redondo, O., A. Herrero, J. F. Bello, M. G. Roig, M. V. Calvo, F. J. Plou, and F. J. Burguillo. 1995. Comparative kinetic study of lipases A and B from Candida rugosa in the hydrolysis of lipid p-nitrophenyl esters in mixed micells with Triton X-100. Biochim. Biophys. Acta 1243:15-24.

Richardson, G. H., and J. H. Nelson. 1967. Assay and characterization of pregastric esterase. J. Dairy Sci. 50:1061-1065.

Ruiz-Sala, P., M. T. G. Hierro, I. Martinez-Castro, and G. Santamaría. 1996. Triglyceride composition of ewe, cow and goat milk fat. J. AOCS 73:283-292.

Villeneuve, P., M. Pina, and J. Graille. 1996. Determination of pregastric lipase specificity in young ruminants. Chem. Phys. Lip. 83:161-168. 